\title{
Alterations of BCCIP, a BRCA2 interacting protein, in astrocytomas

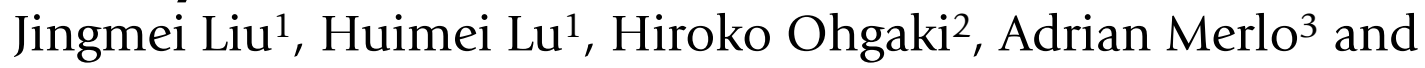 Zhiyuan Shen*1
}

\begin{abstract}
Address: ${ }^{1}$ Department of Radiation Oncology, The Cancer Institute of New Jersey, UMDNJ-Robert Wood Johnson Medical School, 195 Little Albany St, New Brunswick, NJ 08903, USA, 2Pathology Group, International Agency for Research on Cancer, World Health Organization, 150 Cours Albert Thomas, 69372 Lyon Cedex 08, France and ${ }^{3}$ Neurosurgery and Laboratory of Molecular Neuro-Oncology, Departments of Surgery and Research, University Hospitals, Spitalstrasse 21, CH-4031 Basel, Switzerland
\end{abstract}

Email: Jingmei Liu - liuj8@umdnj.edu; Huimei Lu - luhu@umdnj.edu; Hiroko Ohgaki - ohgaki@iarc.fr; Adrian Merlo - amerlo@uhbs.ch; Zhiyuan Shen* - shenzh@umdnj.edu

* Corresponding author

This article is available from: http://www.biomedcentral.com//47/-2407/9/268

(c) 2009 Liu et al; licensee BioMed Central Ltd.

This is an Open Access article distributed under the terms of the Creative Commons Attribution License (http://creativecommons.org/licenses/by/2.0), which permits unrestricted use, distribution, and reproduction in any medium, provided the original work is properly cited.

\begin{abstract}
Background: Loss of heterozygosity of chromosome 10q26 has been shown to be associated with the aggressiveness of astrocytic tumors (or astrocytomas), but the responsible gene(s) residing in this region has not been fully identified. The BCCIP gene is located at chromosome 10q26. It encodes a BRCA2 and CDKNIA (P2I) interacting protein. Previous studies have shown that down-regulation of BCCIP impairs recombinational DNA repair, GI/S cell cycle checkpoint, p53 trans-activation activity, cytokinesis, and chromosome stability, suggesting a potential role of BCCIP in cancer etiology. In this study, we investigated whether BCCIP is altered in astrocytomas.
\end{abstract}

Methods: Genomic DNA from 45 cases of grade IV astrocytic tumor (glioblastoma) tissues and 12 cases of normal tissues were analyzed by quantitative PCR. The BCCIP protein expression in 96 cases of grade II-IV astrocytic tumors was detected by immunohistochemistry (IHC). IHC staining of glial fibrillary acid protein (GFAP), a marker for astrocytic cells, was used to identify cells of the astrocytic lineage.

Results: We found that BCCIP protein is expressed in normal cells with positive staining of GFAP. However, BCCIP protein expression was not detectable in $\sim 45 \%$ of all astrocytic tumors, and in $>$ $60 \%$ in the grade IV glioblastoma. About $45 \%$ glioblastoma have significant $(\mathrm{p}<0.0 \mathrm{I})$ reduction of $B C C I P$ gene copy number when compared to normal DNA. Furthermore, the frequency of lacking $\mathrm{BCCIP}$ expression is associated with the aggressiveness of astrocytic tumors.

Conclusion: Our data implicate a role of BCCIP in astrocytic tumorigenesis, and lack of BCCIP may be used as a marker for astrocytomas.

\section{Background}

Astrocytic tumor, or astrocytoma, is one of the most lethal forms of brain cancer although they rarely metastasize.
Improvement of astrocytoma interventions requires further understanding on the genetic alterations associated with these tumors. Loss of heterozygosity ( $\mathrm{LOH}$ ) of chro- 
mosome 10q (especially region 10q25.3-26.2) is frequently associated with astrocytoma [1-11]. LOH on chromosome $10 \mathrm{q} 26$ is highly correlated with a poor prognosis for astrocytoma [1-7,9-12], and perhaps is the one of the most reliable prognosis markers associated with a worse outcome $[8,9,13]$. Thus, identifying the gene(s) in this region associated with this form of brain tumor is of critical importance for astrocytoma intervention. In addition to brain tumor, LOH of 10q26 has been shown to be associated with prostate cancers, endometrial cancers, and lung cancers [14-17], further suggesting the importance of identifying the tumor related gene(s) on 10q26.

Genomic instability is a major driving force for tumor progression. The BRCA2 gene plays critical roles in the maintenance of genomic stability by regulating homologous recombination, and BRCA2 defects are associated with predisposition to various human cancer. Although mutation of BRCA2 itself is involved in only a small population of human cancer, the germline BRCA2 mutations are highly penetrative to cancer. This suggests that the entire molecular pathway of BRCA2 are critical for cancer prevention, and other proteins related to BRCA2 may contribute to additional tumors [18]. Thus identifications and analyses of novel BRCA2 interacting protein may provide unique opportunities to identify additional genetic factors involved in tumorigenesis. We and others have previously reported BCCIP as a BRCA2 and CDKN1A [19] interacting protein [20-23]. We have shown that the chromatin bound fraction of BCCIP co-localizes with BRCA2 and contributes to BRCA2 and RAD51 nuclear focus formation [22]. A 50\% down-regulation of BCCIP is sufficient to inhibit homologous recombination, and both the BRCA2 and p21 interaction domains of BCCIP play a role in regulating homologous recombination $[22,24,25]$. Furthermore, BCCIP has been shown to play a role in supporting p53 transcription activity, and the completion of cytokinesis during mitosis [26,27]. All these support a critical role of BCCIP in the maintenance of genomic stability.

The human BCCIP gene is located at 10q26.1 [20], and a recent report suggested that BCCIP may be absent in at least one astrocytoma cell line [28]. We previously showed that the A172 astrocytic brain tumor cell line has reduced expression of BCCIP $\alpha$ [20]. Given that BCCIP is involved in important processes relevant to the maintenance of genome stability and its localization at 10q26, we investigated the possibility of BCCIP alterations in more than 100 cases of astrocytomas. Because brain tumor in the astrocyte lineage are the most common type $[29,30]$, we emphasized our analyses on the astrocytic tumors including the grade IV glioblastoma multiforme. We found that BCCIP is down-regulated in a major portion of these brain tumors. Furthermore, BCCIP down- regulation is correlated with the aggressiveness of astrocytomas. These data suggest BCCIP alteration as a new marker for astrocytomas.

\section{Methods \\ Quantitative Real-Time PCR detection of BCCIP copy number}

A total of 45 cases of anonymous genomic DNA were isolated from grade IV astrocytoma as previously reported $[5,31]$. Twelve cases of DNA from peripheral blood leukocytes were used as control for normal BCCIP gene dosage determination. Real-time PCR was done using the SYBR Green strategy with a DNA Engine Opticon ${ }^{\mathrm{TM}} 2$ Real-Time Detection System (M J Research Inc. South San Francisco, CA). Each pair of primers was optimized to amplify only the anticipated PCR products, which were verified by DNA sequencing and melting curve analysis. The primers for BCCIP are as follows: exon 5: 5'-TGC TTT CTA GGG TAC CCA GTG-3' (forward) and 5'-CCA CAG GCT TGG TGG TGT C-3'(reverse, 129 bp); exon 6: 5'-GGC ACA CAG AAC CAA TAA GCC-3' (forward) and 5'-CAT TTG CAA ACA TTA ACG CAG C-3' (reverse, 136 bp); exon 7: 5'-TCA ACT ACT CAG TGC AGG AGG AG-3' (forward) and 5'CAG TTT ATC CAT GAT TTC GTT CAT C-3' (reverse, 135 bp); exon 9: 5'-AAG TGA CAG CCC TGG TTT CTC-3' (forward) and 5'-ATG AGC CTC CTA AAT CCC TGA C-3' (reverse, $130 \mathrm{bp}$ ). To normalize the copy number of BCCIP gene, the copy number of glyseraldehyde-3-phosphate dehydrogenase (GAPDH) was used as an internal control. The primers for GAPDH are: 5'-AAC GTG TCA GTG GTG GAC CTG-3' (forward) and 5'-AGT GGG TGT CGC TGT TGA AGT-3' (reverse, 160 bp), as validated and described previously $[5,32]$. This pair of primers amplifies a single band as confirmed by melting curve analysis with the DNA Engine Opticon ${ }^{\mathrm{TM}} 2$ Real-Time Detection System (M J Research Inc. South San Francisco, CA), and confirmed to be the coding gene of GAPDH by DNA sequencing. To our knowledge, this pair of primer does not amply GAPDH pseudogenes. In each PCR analyses, we used 25 $\mu \mathrm{l}$ of reaction volume containing $4 \mu \mathrm{l}$ of DNA, $100 \mu \mathrm{M}$ each of the primers, and $12.5 \mu$ l of $2 \times$ master mix from DyNAmo HS SYBR Green qPCR kit (Finnzymes). Standard curve to calibrate DNA concentration was performed for all amplifications for each pair of primers. The PCR reaction tubes were first incubated for 15 minutes at $95^{\circ} \mathrm{C}$, followed by 40 cycles of 30 seconds at $95^{\circ} \mathrm{C}, 20$ seconds at optimized annealing temperature depending on the primers, and 20 seconds at $72^{\circ} \mathrm{C}$.

\section{Antibodies and Immunohistochemistry of BCCIP and GFAP in brain tumors}

Rabbit anti-BCCIP $\alpha / \beta$ antibodies were reported previously [20]. Paraffin embedded brain tumor tissue array slides (Catalog No GL801, BS17001, and BS17014) were purchased from US Biomax (Rockvile, MD). The core 
diameter is $1.5 \mathrm{~mm}$, and the slides have thickness of $5 \mu \mathrm{m}$. The pathological grade of tumor on the array were provided by the slide supplier, and later confirmed by us when the slides were evaluated. The astrocytoma grade IIIV in pathology diagnosis is equivalent to low-grade moderately-differentiated astrocytoma, anaplastic astrocytoma, and undifferentiated glioblastoma multiforme respectively. These slides originally contain more than 100 cases of independent astrocytoma, 12 cases of oligodendroglioma, and 5 cases of ependymomas. Some of the cases were eliminated from data analysis due to lack of tumor tissues on the cores of the particular cases. This was caused by tissue detachment from the slides during the staining process, or because the presence of tumor tissue cannot be verified. Thus, a total 96 cases of astrocytomas, 6 cases of oligodendrogliomas, and 5 cases of ependymomas are reported here. Because objective of this study is to perform a retrospective determination on whether BCCIP is altered in existing specimens without contacting with living individual, no information on the patient identities and clinical outcomes are available for the investigators, approval for human subject research was deemed unnecessary.

The astrocytomas are in the astrocytic lineage, and the astrocytic cells often express a unique marker glial fibrillary acid protein (GFAP). Based on staining of non-tumor brain tissue, BCCIP is not uniformly expressed in brain tissue, but its expression can be detected in GFAP positive cells (see Results section). Therefore, we stained GFAP to identify the astrocytic tumor cells in the sections. Double staining of the same slide with GFAP and BCCIP turned out to be challenging with the available antibodies. Thus, two neighboring serial sections of these slides were stained with anti-GFAP monoclonal antibody (Chemicon International, Temecula, CA) and anti-BCCIP antibody respectively using routine immunohistochemistry (IHC) protocols. Briefly, slides were de-paraffinized with xylene for $10 \mathrm{~min}$, and repeated three times. The antigen was retrieved in citrate acid buffer ( $\mathrm{pH6.5)}$ by steaming in a rice cooker for $20 \mathrm{~min}$. Following antigen retrieval, the endogenous peroxidase activity was blocked at room temperature by 20 minutes of incubation with $1 \% \mathrm{H}_{2} \mathrm{O}_{2}$ in methanol. The slides were blocked with 5\% milk in TBS-T (25 mM Tris- $\mathrm{HCl}$ pH 7.5, $150 \mathrm{mM} \mathrm{NaCl}, 0.1 \%$ Tween20) for $30 \mathrm{~min}$ at room temperature, and then incubated with 1:100 diluted affinity-purified rabbit polyclonal antiBCCIP antibodies for 3 hrs at room temperature. This BCCIP antibody has been reported previously [20].

Following 3 times wash with TBS-T, the slides were incubated for $1 \mathrm{hr}$ at room temperature with anti-Rabbit IgG secondary antibody $(1: 100)$ that was conjugated with horseradish peroxidase. The chromogenic substrate diaminobenzidine (DAB) was used as a chromogen to stain BCCIP positive cells (brown color). Haematoxylin was used as contrast staining for BCCIP negative cell nuclei (blue color). After mounting, the slides were observed under microscope. When the BCCIP nuclear stain was found in less than $5 \%$ of tumor cells, the case was scored as BCCIP negative. When more than 5\% tumor cells are stained BCCIP positive, the case was considered BCCIP positive. For GFAP staining and evaluation, the same as BCCIP was used, except anti-GFAP monoclonal antibody was used as first antibody, and anti- mouse IgG $(1: 100)$ was used as the secondary antibody which was conjugated with horseradish peroxidase.

\section{Results \\ Reduction of BCCIP gene dosage in brain tumors}

The BCCIP gene is located at chromosome 10q26.2 [20], a region frequently altered in brain tumors. The BCCIP gene also functions in cell cycle control, homologous recombination, mitosis, and is required to maintain the transactivation activity of wild type p53 [19,22-24,26,27]. Therefore, we were interested in determining whether altered BCCIP is associated with brain tumors. We first estimated the BCCIP gene copy numbers in genomic DNA from 45 cases of glioblastomas (grade IV). Due to the limited amount DNA available for this study, we used quantitative PCR to assess the BCCIP gene dosage. We performed Real-Time PCR using four independent sets of primers within exons 5, 6, 7, and 9 of BCCIP according to the genomic structure reported previously [33]. First, the relative level of BCCIP gene was determined from DNA of lymphocytes (see Methods). This provides a spectrum of BCCIP signals in normal tissues. The average of these signals from the normal DNA, and its standard deviation were calculated. Based on the Gaussian (or normal) distribution, the 99\% confidence limit $(\mathrm{p}<0.01)$ was set at 2.58 fold of the standard deviation, and the 95\% confidence limit $(P<0.05)$ was set at 1.96 fold of the standard deviation. Then, the relative dosage of BCCIP gene in tumor DNA was compared with the distribution of normal DNA. If the copy numbers of two independent BCCIP exons are less than the $99 \%$ confidence line of the normal DNA, a "BCCIP loss" was scored for this case of tumor. We found that 20 out of 45 cases of glioblastoma DNA have significant loss of BCCIP with $\mathrm{p}<0.01$, an overall rate of $44.5 \%$. In addition, 14 cases (31.1\%) have BCCIP loss with $0.01<\mathrm{p}<0.05$. Thus a total of $\sim 75 \%$ glioblastomas have BCCIP loss $(\mathrm{p}<0.05)$. It was worth-noting that five cases of brain tumors (labeled as case A, B, C, D, and E in Figure 1) have reduced copy numbers in some exons, but higher copy numbers in other parts of the gene, indicating that other types of alteration such as regional amplification of the gene could have occurred in addition to deletion. Southern blot analyses for these tumor DNAs were impossible due to lack of sufficient DNA specimens. Nev- 




\section{Figure I}

Copy numbers of BCCIP exons detected by quantitative Real-Time PCR. The copy number of exons 5, 6, 7, and 9 were measured in 10 cases of normal brain tissue DNA (diamond marker), and 45 cases of glioblastoma DNA (see Materials and Methods for details). The $95 \%$ and $99 \%$ confidence ranges of the copy number in normal tissues are marked. Many tumor DNAs showed reduction of BCCIP copy numbers. However, five cases of tumor DNA (marked as cases A-E) have reduced BCCIP copy numbers at some exons but increased in others. These re-arrangements likely cause inactivation of the BCCIP gene.

ertheless, our data indicate that BCCIP gene loss or alteration is common in glioblastomas.

\section{Loss of BCCIP protein expression in brain tumor}

To confirm the loss of BCCIP, we measured the BCCIP protein expression in brain tumor tissue sections. These cases were not related to the cases presented in Figure 1, but were obtained from an independent source (US Biomax, Rockvile, MD) in the form of tissue arrays, because no tissue slides were available for the same cases as reported in Figure 1. The pathological grades of these tumors were provided by the supplier of the tissue arrays, but confirmed by experienced pathologist co-authors (HL and $\mathrm{HO}$ ) based on the sections. Because majority of the tumor on the slides are astrocytoma, and most astrocytic tumor cells express the unique marker glial fibrillary acid protein (GFAP) [34,35], we first checked if BCCIP is expressed in normal GFAP positive cells. Using serial sections to stain normal brain tissue with anti-GFAP and anti-BCCIP antibodies (Figure 2, top panels), we found that BCCIP protein is mainly expressed in GFAP positive cells.

Then, we stained serial sections of the tumor tissue arrays with anti-GFAP and anti-BCCIP antibodies. Because BCCIP is mainly expressed in GFAP positive cells, we grouped the tumors based on their GFAP status (Table 1). As shown in Table 1, among 91 cases of GFAP positive astrocytomas, 40 were BCCIP negative, an overall rate of $44.8 \%$. Three of the five GFAP negative astrocytomas are also BCCIP negative. It has been established that alteration of 10q25.3-26.1 is associated with high grade and poor prognosis of astrocytic tumors [7-9,36]. Interestingly, we found that 5 out of 26 cases $(19.2 \%)$ WHO 


\section{Normal tissue \\ Astrocytoma Tissue BCCIP (+) $(53 / 96=55.2 \%)$ \\ Astrocytoma Tissue BCCIP(-) $(43 / 96=44.8 \%)$}
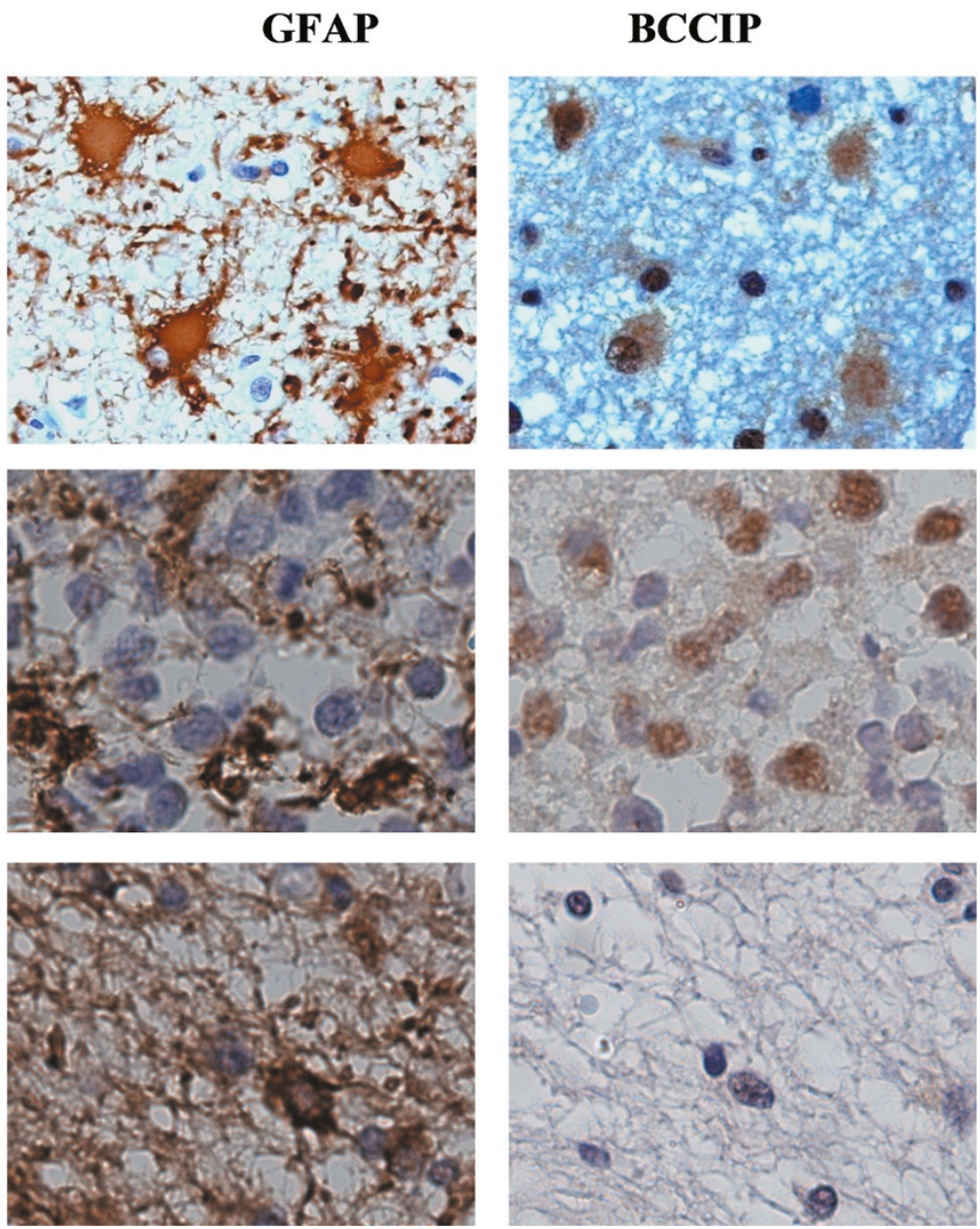

\section{Figure 2}

Lack of BCCIP expression in brain tumors. Serial tissue sections were stained for GFAP and BCCIP separately. Both GFAP and BCCIP are stained in brown color. Hematoxylin (blue) was used to counter stain the nuclei. Shown are example brain tissues stained with antibodies against GFAP and BCCIP (magnification is $40 \times 10$ ). Top panel is a representative nontumor section. The middle panel is an example section of BCCIP positive tumor, and the bottom panel shows a BCCIP negative tumor section.

grade II astrocytomas are BCCIP negative, whereas 13/29 $(44.8 \%)$ WHO grade III and 25/41 (60.1\%) WHO grade IV astrocytomas are BCCIP negative (Figure 3 ). Based on a Chi-square test, there is a statistically higher frequency of BCCIP negativity in grade III $(\mathrm{p}<0.05)$ and IV $(\mathrm{p}<0.01)$ tumors than that of the grade II tumors, but there was no statistic difference between grades III and IV ( $p>0.05)$. The correlation of lacking BCCIP expression with the WHO grade is consistent with the association between $10 \mathrm{q} 26$ abnormalities and the poor prognosis of astrocytomas [7-9,36]. In addition, 2 out 6 GFAP positive oligodendroglioma are BCCIP negative, and all 5 cases of ependymomas are GFAP negative but BCCIP positive.

\section{Discussion}

Cytogenetic and $\mathrm{LOH}$ analyses have suggested that at least three distinct regions of the long arm of chromosome 10 are related to brain tumorigenesis: 10q23.3, 10q24-25, and 10q25.3-26.2. The tumor susceptibility gene located at 10q23.3 has been identified as the PTEN (phosphatase and tension homologue detected on chromosome TEN) or MMAC (mutated in multiple advanced cancers) gene. PTEN/MMAC protein has two distinct structural domains, the phosphatase domain and a C2 domain that binds phospholipid membranes in vitro [37]. PTEN mutations have been identified in a variety of human cancers [3841]. A second tumor susceptibility gene is located at 10q24-25. The c-Myc, Max homologous gene MXI1 is located in this region $[17,42-50]$. 

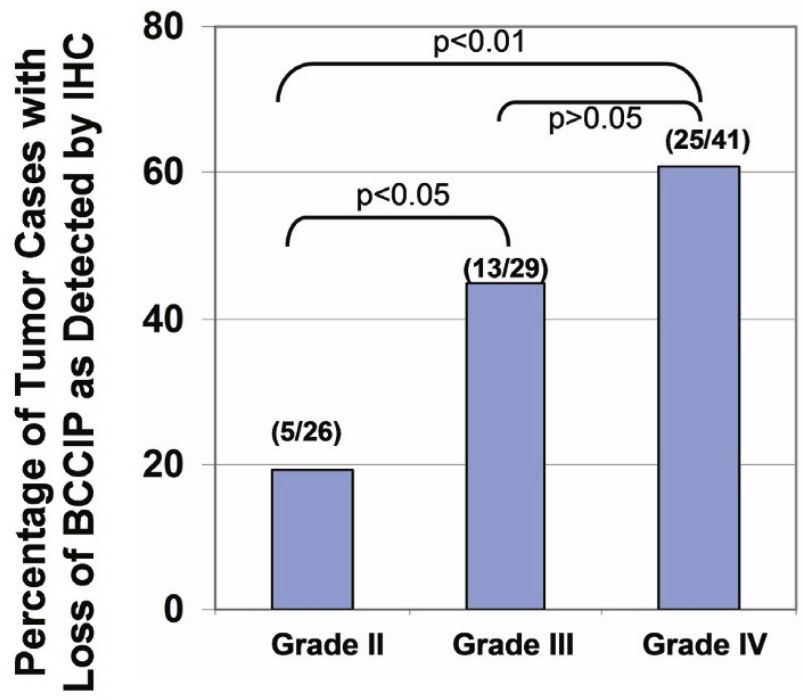

\section{WHO Grade of Astrocytoma}

Figure 3

Frequency of loss of BCCIP protein expression in different WHO grades of astrocytomas [30]. Shown is the percentage of astrocytomas that are BCCIP negative. The $\mathrm{P}$ values indicate the statistic values between the indicated tumor grade groups.

A putative tumor susceptibility gene DMBT1 (Deleted in Malignant Brain Tumors) has been identified in 10q25.326.2. [51]. DMBT1 is homologous to the scavenger receptor cysteine-rich (SRCR) superfamily of proteins. Since it is deleted in a large proportion of brain tumors, it has been suggested as a candidate for the tumor susceptibility gene in this region. However, expression of DMBT1 in tumor cells has little effect on tumor cell growth or tumor associated phenotypes [4,52-54]. This opens the possibility that additional genes in this region may be relevant to brain tumorigenesis. Considering that: 1) BCCIP interacts with BRCA2 and p21, 2) BCCIP plays a role in homologous recombination, cell cycle regulation, p53 transcription activity, and chromosome instability [19-24,26,27], 3) BCCIP expression is absent in a significant portion of astrocytomas (Figure 2), and 4 ) the lack of BCCIP expression is correlated with the aggressiveness of astrocytomas (Figure 3), we suggest that BCCIP is a strong candidate for the tumor suppressor gene in the chromosome 10q26 region. However, additional investigation, preferably with animal knock-out or knock-down models, is needed to conclude whether BCCIP defects directly cause brain tumor. It should be pointed out that the 10q26.2 region has been implicated in many other cancer types. The role of BCCIP in other cancer types warrants additional investigations.

Mutation of p53 has been reported in 31\% of brain tumor, but $\mathrm{LOH}$ of the $10 \mathrm{q}$ region has been reported in $69 \%$ of brain tumor [9]. Despite that majority of the brain tumor harbors wild type p53, brain tumors are well known for their radiation resistance. We reported that in the absence of BCCIP, the transactivation activity of wild type p53 protein is not sustainable [26]. Down-regulation of BCCIP leads to a resistance to ionizing radiation of HCT116 cells with wild type p53 [26]. It has been recently shown that lack of BCCIP in p53 wild type laryngeal cancer is associated with poor progress in response to radia-

Table I: Number of cases analyzed by IHC on tissue array

\begin{tabular}{|c|c|c|c|c|c|c|}
\hline & \multicolumn{3}{|c|}{ GFAP (+) } & \multicolumn{3}{|c|}{ GFAP (-) } \\
\hline & $\mathrm{BCCIP}(+)$ & BCCIP (-) & Total & $\mathrm{BCCIP}(+)$ & BCCIP (-) & Total \\
\hline \multicolumn{7}{|l|}{ Astrocytic tumors } \\
\hline $\begin{array}{r}\text { Astrocytoma } \\
\text { (Grade II) }\end{array}$ & 21 & 5 & 26 & & & \\
\hline $\begin{array}{r}\text { Anaplastic Astrocytoma } \\
\text { (Grade III) }\end{array}$ & 14 & 12 & 26 & 2 & 1 & 3 \\
\hline $\begin{array}{r}\text { Glioblstoma } \\
\text { (Grade IV) }\end{array}$ & 16 & 23 & 39 & 0 & 2 & 2 \\
\hline Total & 51 & 40 & 91 & 2 & 3 & 5 \\
\hline \multicolumn{7}{|l|}{ Oligodendroglioma } \\
\hline $\begin{array}{r}\text { Oligodendroglioma } \\
\text { (Grade II) }\end{array}$ & 1 & 1 & 2 & & & \\
\hline $\begin{array}{r}\text { Anaplastic Oligodendroglioma } \\
\text { (Grade III) }\end{array}$ & 3 & 1 & 4 & & & \\
\hline Total & 4 & 2 & 6 & & & \\
\hline Ependymoma & & & & 5 & 0 & 5 \\
\hline Total & & & & 5 & 0 & 5 \\
\hline
\end{tabular}


tion therapy [55]. Here we show that a significant portion of astrocytomas has down-regulation of BCCIP. It would be interesting to determine whether the lack of BCCIP expression plays a role in the radiation resistance for these brain tumors with wild type p53.

The dependence of p53 function on BCCIP makes an ideal argument that BCCIP may function as a tumor suppressor, and BCCIP defects are responsible for astrocytoma aggression and resistant to radiation therapy. Because BCCIP has also been shown to be required for completion of mitosis, and severe knockdown of BCCIP resulted in growth retardation in other cell types [27], it remains to be addressed how loss of BCCIP expression may lead to brain tumor survival. Thus, it is likely that lack of BCCIP expression needs to be coupled with additional genetic alterations for tumor cells to be viable and remain aggressive. If this is true, then identification of these additional genetic factor(s) enabling BCCIP defective cells to survive is a critical issue for future studies.

\section{Conclusion}

We found that BCCIP expression is down-regulated in a significant portion of astrocytomas, and the loss of BCCIP expression is more frequent in the aggressive form of astrocytomas. These data suggest BCCIP as a potential marker for brain tumorigenesis.

\section{Competing interests}

The authors declare that they have no competing interests.

\section{Authors' contributions}

JL designed and conducted the quantitative PCR analysis, and drafted a portion of the manuscript. HL conducted the IHC experiments and drafted a portion of the manuscript. ZS designed the study, performed data analysis, and finalized the manuscript, $\mathrm{HO}$ provided $1 / 3$ of the DNA samples and evaluated some of the IHC slides, AM provided the $2 / 3$ of tumor DNA samples. Both $\mathrm{HO}$ and AM provided inputs on improving an early draft of the manuscript.

\section{Acknowledgements}

This research was supported by National Institute of Health grants CAII5488.

\section{References}

I. Rasheed BK, Fuller GN, Friedman AH, Bigner DD, Bigner SH: Loss of heterozygosity for $10 \mathrm{q}$ loci in human gliomas. Genes Chromosomes Cancer 1992, 5:75-82.

2. Karlbom AE, James CD, Boethius J, Cavenee WK, Collins VP, Nordenskjold $M$, Larsson C: Loss of heterozygosity in malignant gliomas involves at least three distinct regions on chromosome 10. Hum Genet 1993, 92:169-74.

3. Balesaria S, Brock C, Bower M, Clark J, Nicholson SK, Lewis P, de Sanctis S, Evans H, Peterson D, Mendoza N, et al.: Loss of chromosome $\mathbf{1 0}$ is an independent prognostic factor in high-grade gliomas. $\mathrm{Br} J$ Cancer $1999,81: 137 \mid-7$.
4. Steck PA, Lin H, Langford LA, Jasser SA, Koul D, Yung WK, Pershouse MA: Functional and molecular analyses of $10 \mathrm{q}$ deletions in human gliomas. Genes Chromosomes Cancer 1999, 24:135-43.

5. Fujisawa H, Reis RM, Nakamura M, Colella S, Yonekawa Y, Kleihues $P$, Ohgaki $H$ : Loss of heterozygosity on chromosome 10 is more extensive in primary (de novo) than in secondary glioblastomas. Lab Invest 2000, 80:65-72.

6. Daido S, Takao S, Tamiya T, Ono Y, Terada K, Ito S, Ouchida M, Date I, Ohmoto T, Shimizu K: Loss of heterozygosity on chromosome $\mathrm{IOq}$ associated with malignancy and prognosis in astrocytic tumors, and discovery of novel loss regions. Oncol Rep 2004, I 2:789-95.

7. Hill C, Hunter SB, Brat DJ: Genetic markers in glioblastoma: prognostic significance and future therapeutic implications. Adv Anat Pathol 2003, 10:212-7.

8. Ohgaki H: Genetic pathways to glioblastomas. Neuropathology 2005, 25:1-7.

9. Ohgaki H, Dessen P, Jourde B, Horstmann S, Nishikawa T, Di Patre PL, Burkhard C, Schuler D, Probst-Hensch NM, Maiorka PC, et al.: Genetic pathways to glioblastoma: a population-based study. Cancer Res 2004, 64:6892-9.

10. Merlo A: Genes and pathways driving glioblastomas in humans and murine disease models. Neurosurg Rev 2003 , 26: |45-58.

II. Maier D, Zhang Z, Taylor E, Hamou MF, Gratzl O, Van Meir EG, Scott RJ, Merlo A: Somatic deletion mapping on chromosome 10 and sequence analysis of $P$ TEN/MMACI point to the $10 q 25-$ 26 region as the primary target in low-grade and high-grade gliomas. Oncogene 1998, 16:3331-5.

12. Ohgaki H, Kleihues P: Population-based studies on incidence, survival rates, and genetic alterations in astrocytic and oligodendroglial gliomas. J Neuropathol Exp Neurol 2005, 64:479-89.

13. Homma T, Fukushima T, Vaccarella S, Yonekawa Y, Di Patre PL, Franceschi S, Ohgaki H: Correlation among pathology, genotype, and patient outcomes in glioblastoma. J Neuropathol Exp Neurol 2006, 65:846-54.

14. Ittmann M: Allelic loss on chromosome 10 in prostate adenocarcinoma. Cancer Res 1996, 56:2143-7.

15. Ittmann MM: Chromosome 10 alterations in prostate adenocarcinoma (review). Oncol Rep 1998, 5:1329-35.

16. Peiffer SL, Herzog TJ, Tribune DJ, Mutch DG, Gersell DJ, Goodfellow $P J:$ Allelic loss of sequences from the long arm of chromosome 10 and replication errors in endometrial cancers. Cancer Res 1995, 55:1922-6.

17. Petersen S, Wolf G, Bockmuhl U, Gellert K, Dietel M, Petersen I: Allelic loss on chromosome $\mathrm{IOq}_{\mathrm{O}}$ human lung cancer: association with tumour progression and metastatic phenotype. Br J Cancer 1998, 77:270-6.

18. Couzin J: The twists and turns in BRCA's path. Science 2003, 302:591-3.

19. Meng X, Lu H, Shen Z: BCCIP functions through p53 to regulate the expression of p2IWafI/Cipl. Cell Cycle 2004, 3:1457-62.

20. Liu J, Yuan Y, Huan J, Shen Z: Inhibition of breast and brain cancer cell growth by BCCIPalpha, an evolutionarily conserved nuclear protein that interacts with BRCA2. Oncogene 200I, 20:336-45.

21. Ono T, Kitaura H, Ugai H, Murata T, Yokoyama KK, Iguchi-Ariga SM, Ariga $\mathrm{H}$ : TOK-I, a novel p2 ICipl-binding protein that cooperatively enhances p $2 \mathrm{I}$-dependent inhibitory activity toward CDK2 kinase. J Biol Chem 2000, 275:3 I |45-54.

22. Lu H, Guo X, Meng X, Liu J, Allen C, Wray J, Nickoloff JA, Shen Z: The BRCA2-interacting protein BCCIP functions in RAD5 I and BRCA2 focus formation and homologous recombinational repair. Mol Cell Biol 2005, 25:1949-57.

23. Meng X, Liu J, Shen Z: Inhibition of $\mathbf{G} \mathbf{I}$ to $\mathbf{S}$ cell cycle progression by BCCIP beta. Cell Cycle 2004, 3:343-8.

24. Lu H, Yue J, Meng X, Nickoloff JA, Shen Z: BCCIP regulates homologous recombination by distinct domains and suppresses spontaneous DNA damage. Nucleic Acids Res 2007, 35:7160-7170.

25. Wray J, Liu J, Nickoloff JA, Shen Z: Distinct RAD5 I associations with RAD52 and BCCIP in response to DNA damage and replication stress. Cancer Research 2008, 68:2699-2707. 
26. Meng X, Yue J, Liu Z, Shen Z: Abrogation of the transactivation activity of p53 by BCCIP down-regulation. J Biol Chem 2007, 282: $1570-6$.

27. Meng X, Fan J, Shen Z: Roles of BCCIP in chromosome stability and cytokinesis. Oncogene 2007, 26:6253-60.

28. Roversi G, Pfundt R, Moroni RF, Magnani I, van Reijmersdal S, Pollo $B$, Straatman H, Larizza L, Schoenmakers EF: Identification of novel genomic markers related to progression to glioblastoma through genomic profiling of $\mathbf{2 5}$ primary glioma cell lines. Oncogene 2006, 25: | 57|-83.

29. Reifenberger G, Collins VP: Pathology and molecular genetics of astrocytic gliomas. J Mol Med 2004, 82:656-70.

30. Kleihues P, Louis DN, Scheithauer BW, Rorke LB, Reifenberger G Burger PC, Cavenee WK: The WHO classification of tumors of the nervous system. J Neuropathol Exp Neurol 2002, 6 I :2 I 5-25. discussion 226-9.

31. Maier D, Comparone D, Taylor E, Zhang Z, Gratzl O, Van Meir EG, Scott RJ, Merlo A: New deletion in low-grade oligodendroglioma at the glioblastoma suppressor locus on chromosome I 0q25-26. Oncogene 1997, 1 5:997-1000.

32. Watanabe T, Nakamura M, Yonekawa Y, Kleihues P, Ohgaki H: Promoter hypermethylation and homozygous deletion of the pI 4ARF and pI6INK4a genes in oligodendrogliomas. Acta Neuropathol 200I, I0 I:185-9.

33. Meng X, Liu J, Shen Z: Genomic structure of the human BCCIP gene and its expression in cancer. Gene 2003, 302:139-46.

34. Shih $\mathrm{AH}$, Holland EC: Developmental neurobiology and the origin of brain tumors. J Neurooncol 2004, 70:125-36.

35. Eng LF, Ghirnikar RS: GFAP and astrogliosis. Brain Pathol 1994, 4:229-37.

36. Fujisawa $H$, Kurrer $M$, Reis RM, Yonekawa $Y$, Kleihues $P$, Ohgaki $H$ Acquisition of the glioblastoma phenotype during astrocytoma progression is associated with loss of heterozygosity on I0q25-qter. Am J Pathol 1999, I 55:387-94.

37. Lee JO, Yang H, Georgescu MM, Di Cristofano A, Maehama T, Shi Y, Dixon JE, Pandolfi P, Pavletich NP: Crystal structure of the PTEN tumor suppressor: implications for its phosphoinositide phosphatase activity and membrane association. Cell I999, 99:323-34

38. Rossi DJ, Weissman IL: Pten, tumorigenesis, and stem cell selfrenewal. Cell 2006, I25:229-3I.

39. Chow LM, Baker SJ: PTEN function in normal and neoplastic growth. Cancer Lett 2006, 24I: I84-96.

40. Stiles B, Groszer M, Wang S, Jiao J, Wu H: PTENless means more. Dev Biol 2004, 273:175-84.

4I. Leslie NR, Downes CP: PTEN function: how normal cells control it and tumour cells lose it. Biochem J 2004, 382: I-I I.

42. Scott DK, Straughton D, Cole M, Bailey S, Ellison DW, Clifford SC: Identification and analysis of tumor suppressor loci at chromosome I0q23.3-I0q25.3 in medulloblastoma. Cell Cycle 2006, 5:2381-9.

43. Ariyanayagam-Baksh SM, Baksh FK, Swalsky PA, Finkelstein SD: Loss of heterozygosity in the $\mathrm{MXII}$ gene is a frequent occurrence in melanoma. Mod Pathol 2003, 16:992-5.

44. Herbst RA, Podewski EK, Mommert S, Kapp A, Weiss J: PTEN and MXII allelic loss on chromosome $\mathbf{I O q}$ is rare in melanoma in vivo. Arch Dermatol Res 1999, 291:567-9.

45. Prochownik EV, Eagle Grove L, Deubler D, Zhu XL, Stephenson RA Rohr LR, Yin X, Brothman AR: Commonly occurring loss and mutation of the MXII gene in prostate cancer. Genes Chromosomes Cancer 1998, 22:295-304.

46. Kuczyk MA, Serth J, Bokemeyer C, Schwede J, Herrmann R, Machtens S, Grunewald V, Hofner K, Jonas U: The MXII tumor suppressor gene is not mutated in primary prostate cancer. Oncol Rep 1998, 5:213-6.

47. Wechsler DS, Shelly CA, Petroff CA, Dang CV: MXII, a putative tumor suppressor gene, suppresses growth of human glioblastoma cells. Cancer Res 1997, 57:4905-12.

48. Kim SK, Ro JY, Kemp BL, Lee JS, Kwon TJ, Hong WK, Mao L: Identification of two distinct tumor-suppressor loci on the long arm of chromosome 10 in small cell lung cancer. Oncogene 1998, I 7:1749-53.

49. Wang DS, Rieger-Christ K, Latini JM, Moinzadeh A, Stoffel J, Pezza JA Saini K, Libertino JA, Summerhayes IC: Molecular analysis of PTEN and MXII in primary bladder carcinoma. Int J Cancer 2000, 88:620-5.
50. Delnatte C, Sanlaville D, Mougenot JF, Vermeesch JR, Houdayer C, Blois MC, Genevieve D, Goulet O, Fryns JP, Jaubert F, et al.: MXII, a putative tumor suppressor gene, suppresses growth of human glioblastoma cells. Am J Hum Genet 2006, 78: 1066-74.

5I. Mollenhauer J, Wiemann S, Scheurlen W, Korn B, Hayashi Y, Wilgenbus KK, von Deimling A, Poustka A: DMBTI, a new member of the SRCR superfamily, on chromosome I0q25.3-26.I is deleted in malignant brain tumours. Nat Genet 1997, I 7:32-9.

52. Sasaki H, Betensky RA, Cairncross JG, Louis DN: DMBTI polymorphisms: relationship to malignant glioma tumorigenesis. Cancer Res 2002, 62:1790-6.

53. Sanson $M$, Leuraud $P$, Aguirre-Cruz L, He J, Marie $Y$, Cartalat-Carel $S$ Mokhtari K, Duffau H, Delattre JY, Hoang-Xuan K: Analysis of loss of chromosome IOq, DMBTI homozygous deletions, and PTEN mutations in oligodendrogliomas. J Neurosurg 2002, 97:|397-40|

54. Pang JC, Dong Z, Zhang R, Liu Y, Zhou LF, Chan BW, Poon WS, Ng HK: Mutation analysis of DMBTI in glioblastoma, medulloblastoma and oligodendroglial tumors. Int J Cancer 2003, I05:76-8I.

55. Rewari A, Lu H, Parikh R, Yang Q, Shen Z, Haffty BG: BCCIP as a prognostic marker for radiotherapy of laryngeal cancer. Radiother Oncol 2009, 90:183-8.

\section{Pre-publication history}

The pre-publication history for this paper can be accessed here:

http://www.biomedcentral.com/1471-2407/9/268/pre pub
Publish with Bio Med Central and every scientist can read your work free of charge

"BioMed Central will be the most significant development for disseminating the results of biomedical research in our lifetime. "

Sir Paul Nurse, Cancer Research UK

Your research papers will be:

- available free of charge to the entire biomedical community

- peer reviewed and published immediately upon acceptance

- cited in PubMed and archived on PubMed Central

- yours - you keep the copyright
BioMedcentral 